\title{
A state church? \\ A consideration of the Methodist Church of Southern Africa in the light of Dietrich Bonhoeffer's 'Theological position paper on state and church'
}

\author{
Forster, Dion \\ Stellenbosch University \\ dionforster@sun.ac.za
}

\begin{abstract}
This article considers whether South Africa's largest mainline Christian denomination, the Methodist Church of Southern Africa, is in danger of embodying or propagating a contemporary form of 'state theology'. The notion of state theology in the South African context gained prominence through the publication of the 'Kairos Document' (1985) - which celebrated its thirtieth anniversary in 2015. State theology is deemed inappropriate and harmful to the identity and work of both the Christian church and the nation state. This article presents its consideration of whether the Methodist Church of Southern Africa is in danger of propagating 'state theology' in dialogue with Dietrich Bonhoeffer's important document, Theological Position Paper on State and Church. The article offers some insights into the complex relationship between the state and the church in South Africa in the apartheid and democratic eras. It further problematizes the relationship between the Methodist Church of Southern Africa and the governing African National Congress by citing some concerning examples of complicit behaviour from recent history. The MCSA's polity and doctrine on church and state relationships are also considered before some critique and warning is offered in the light of Bonhoeffer's Theological Position Paper on State and Church.
\end{abstract}

Keywords

Bonhoeffer, Church and state, Political theology, Methodism, John Wesley, Ethics, Methodist Church of Southern Africa, Ecclesiology

\section{Introduction}

This article facilitates a critical theological conversation between Dietrich Bonhoeffer's important document, Theological Position Paper on State and 
Church (DBWE 16:502-528, Bonhoeffer in Green 699-716) and to a lesser extent, The Church and the Jewish Question (DBWE 12:361-370, Bonhoeffer in Green, 370-378), with one of South Africa's prominent mainline Christian denominations - the Methodist Church of Southern Africa (MCSA). The conversation takes place within the context of renewed interest in the theology of the 1985 South African Kairos document; particularly in terms of the Kairos document's notion of state theology.

It will be important to avoid simply collapsing Bonhoeffer's concepts of church and state in the aforementioned documents into the contemporary South African context of the MCSA. There are important, critical, hermeneutic considerations that must be kept in mind in such a historical dialogue. ${ }^{1}$ As such the article seeks to carefully facilitate a dialogue that can help the reader to understand and grapple with the complexity of the relationship between the church and the state in South Africa at present, and consider some cautions and warnings that emerge from a contemporary reading of Dietrich Bonhoeffer's Theological Position Paper on State and Church while being conscious of the context in which Bonhoeffer wrote that document. Its historical location does not invalidate its contribution for contemporary use, rather a careful and responsible reading allows for meaningful and credible insight into contemporary issues that relate in differing ways to Bonhoeffer's context and concerns.

South Africa has a complex and conflicted history of the relationship between the church and the state. The complexity of this issue is, at times, amplified by the presence of dominant power that is held by particular Christian denominations and political parties at different times in South African history. Perhaps the most widely considered of these relationships was that between the South African Nationalist government and the Dutch Reformed Church in South Africa during the apartheid era (cf. Elphick \& Davenport 1997; De Gruchy 2005; Elphick, 2012). The nexus of political power and social influence held by these two domains of society led to

1 Among others, my view on the importance of hermeneutic considerations in relation to the use and interpretation of historical documents is shaped by the recent book of Lategan - for a detailed and helpful discussion of the complexity of building a hermeneutic bridge between the world and intention of the context of the original historical document, the intention of the author and the contemporary reader and context please see (Lategan 2015:29-39, 49-53). 
the contamination of both the state and the church, and resulted in the development and propagation of theological heresy (cf. De Gruchy \& VillaVicencio 1983:81-85) and religiously sanctioned human rights abuses on a mass scale (De Gruchy 2005:46, 52, 97, 145, 256).

During those years of struggle and turmoil the Church in various forms (ecumenical body / denominations, local congregations and communities, and individual members) witnessed in words and deeds against both the heresies and the abuses of apartheid. ${ }^{2}$ The Church and the churches played a significant role in the deconstruction of apartheid in South Africa in a similar manner to how churches throughout the centuries have witnessed against evil in their own times and contexts.

Bonhoeffer explicates this principle of contextual church identity in saying that in relation to the nation the role of the Church is to act as a witness to God's reign calling the government to justice where it is unjust, making it aware of its failures and mistakes that threaten its office, but also to act to 'preserve at least among its own members the order of outward justice no longer present in the polis' (Bonhoeffer in Green \& DeJonge 2013:714).

After 1994 the social actors of power in South African society changed from the National Party and the Dutch Reformed Church. The African National Congress (ANC) is now the governing party in South Africa, while the mainline, largely English speaking, churches (such as the Anglican Church, and Methodist Church of Southern Africa etc.,) now occupy the positions of social prominence and dominance in the religious sphere. The nexus of power is once again challenging the witness and work of the church, as well as the credibility the government in South Africa. The church is now facing the threat of becoming embedded in the actions and intentions of the national state. ${ }^{3}$

2 The use of the term Church in these three forms stems from (Smit, 2007:61-68). However, it was adapted by Forster to be used in the specific manner in which it will be applied in this article (cf. Forster 2015:1-10; Forster \& Oosterbrink 2015:1-9).

3 Edwin Arrison notes that when the 2012 Kairos South Africa document was being discussed among church leaders in South Africa, Denise Ackermann warned the churches and their leaders to 'engage, but not be embedded' in political parties and the aims of the state (Arrison in, Conradie \& Pillay, 2015:12). This in an important distinction in the current relationship between the church and state. 
Hence this article aims to problematize the relationship between the Methodist Church of Southern Africa and the governing party in South Africa, the ANC, from the perspective of an aspect of Dietrich Bonhoeffer's theology of the relationship and responsibility that exists between the church and the state as expressed in his Theological Position Paper on State and Church. Bonhoeffer's theology of the church and the state, as well as John Wesley and early Methodism's theological wellspring, have some important warnings and cautions that can serve both the state and the church in the current South African context.

The concept for this article was sparked by a conversation between a number of Methodist clergy who were concerned that the MCSA was in danger of becoming what they called a 'state church' because of an increasingly complicit relationship between the MCSA and the governing African National Congress (ANC) in South Africa. Of course it would not be possible for the MCSA to be formally characterised as a state church. ${ }^{4}$ in the strict legal sense of this term, since at present the Constitution of the Republic of South Africa does not allow for a state religion of state Church. However, there is some danger of the MCSA falling into the error of 'state theology' as will be shown below.

Second, it must be noted that there are significant differences between Southern African Methodism and the German Confessing Church (which is the ecclesial location from which Dietrich Bonhoeffer wrote his theological position paper).

In order to fulfil this task, the article will begin with a discussion of some aspects of the relationship between the church and the state in South Africa

4 While the constitution of South Africa currently precludes any Church or religious grouping being the formal religion of the state, the conceptual framework within this article is presented, namely the theology of the 1985 Kairos document, does allow one to refer to a particular Church or religious grouping as being the preferred or privileged choice of the state. Moreover, such a religious grouping may defend the state, propagate the ideology of the state, and defend and publicly support senior state functionaries in that sense one could say that such a grouping is a 'state church'. However, to avoid confusion with the formal legal understanding of a state church we shall employ the descriptive term, state theology (i.e., the theological frameworks that inform and shape the identity and action of the church in relation to the state). 
that have taken shape after the emergence of democracy in $1994^{5}$. This will be followed by some remarks on the notion of church as it is understood and used in this argument. Next there will be some discussion of Wesleyan and Methodist perspectives on the relationship between the church and the state, with particular emphasis on Methodism in Southern Africa. The article will conclude by drawing these points together and offering some cautions and suggestions for both the church and the state in South Africa in the light of Bonhoeffer's Theological Position Paper on State and Church.

\section{A state church? The complexity of church and state relationships in post 1994 South Africa, and the present}

In order to understand some of the concerns about the recent developments in the relationship between the church and the state in South Africa it is necessary to look a little further into the past. The perspectives in this article are shaped in the light of the thirtieth anniversary of the Kairos document.

In 2015 the thirtieth anniversary of the South African Kairos document (Kairos Theologians, 1985) was celebrated. This document challenged the church in South Africa to consider how its theological identity and expression of faith in spirituality and worship shaped its presence and witness in society. ${ }^{6}$ It challenged the church to move away from a theology that upholds and furthers the aims of oppressive power (with reference to the apartheid state - known as 'state theology'), or that retreats from society

5 I have attempted, as far as possible, not to use the term 'post-apartheid South Africa'. The primary reason for this is that South Africans do not experience a substantial difference in social relations, economic equality, or standard of living after the 1994 democratic elections. Of course legislated apartheid did end in 1994, however, in the ways in which it matters for South Africa's population very little has changed.

6 The 1985 Kairos document identified three types of dominant theologies at that time in South Africa's history: A state theology that sought to uphold and support the ideology of the state through the church and theology. Next Kairos described a church theology that either sought a middle, 'third way' of compromise, or was completely disengaged from what was taking place in society and the political realm (De Gruchy in Forrester, Storrar \& Morton 2004:51). The document advocated for a prophetic theology that would stand on the side of the oppressed and speak truth to the power of the state, seeking to voice the disapproval and judgment of God on state oppression and the weakness of the church (Kairos Theologians 1985:15-17; De Gruchy in Forrester et al 2004:51; Huber \& Fourie 2012:110-114; Boesak 2015:15). 
and only focuses on the programs and priorities of the church (known as 'church theology'), thus denying the challenges and opportunities that are faced outside of the confines of the gathered worshiping community. The Kairos theologians advocated for a 'prophetic theology', and a 'prophetic church', that would witness to God's will both within the public of the church and the broader publics of society. ${ }^{7}$

We as a group of theologians have been trying to understand the theological significance of this moment in our history. It is serious, very serious. For very many Christians in South Africa this is the Kairos, the moment of grace and opportunity, the favourable time in which God issues a challenge to decisive action. It is a dangerous time because, if this opportunity is missed, and allowed to pass by, the loss for the Church, for the Gospel and for all people of South Africa will be immeasurable (Kairos Theologians 1985:1).

This challenge to the church remains as important today as it was 30 years ago. What the Kairos document did was to remind both the church and the state that each had a specific role to play within God's intended will for society. This has some resonance with Bonhoeffer's understanding of God's will for the state and the church. What makes the Kairos document important is that it not only pointed out errors in the state, but passed judgement upon it.

... the Kairos Document perceived that the church itself was a site of [the Apartheid] struggle... Whereas Cottesloe and the Message did not challenge the legality of the State, the Kairos Document

7 For the use of the term 'public' in this article please refer to Smit, D 'What does 'Public' mean? Questions with a View to Public Theology' (In Hansen 2007:11-46), and Kim, D, Theology in the Public Sphere (Kim 2011:3-26), as well as John de Gruchy, 'Public Theology as Christian Witness: Exploring the Genre' (De Gruchy 2007:26-41). Then, please also see The Paradigm of Public Theology - Origins and Development (Smit 2013) for a helpful historical overview, and philosophical analysis, of the development of the term 'public theology' and development of the discipline of public theology in theological discourse. It is also worth noting that the discipline and terminology are contested in South African theological discourse, please see the following articles as two prominent examples of the diverse perspectives on the role and place of public theology in South Africa, (Maluleke 2011; Nico Koopman 2011). Tshaka has a very insightful analysis of the debate in his article A perspective on notions of spirituality, democracy, social cohesion and public theology in which he offers a balanced and nuanced view of the role of public theology in the South African context (Tshaka 2014:4-5). 
described the state as tyrannical and therefore one that had to be resisted through acts of civil disobedience. (De Gruchy 2005:198).

De Gruchy notes that the apartheid state sought to counter the contentions of the Kairos theologians by working 'in tandem with right wing religious organizations' (2005:197). In other words, parts of the South African church had become agents of the unjust state, expressing support for its views and acting as a social shield to deflect criticism against its policies, actions and theology. There is a fear that this is taking place once again (cf. Tandwa 2016).

The Kairos theologians cautioned that those parts of the church that had either succumbed to 'state theology', or were hiding from the social realities within a form of 'church theology' were in theological error. They are denying their divine responsibility as the church. As Bonhoeffer notes, under Christ the responsibility of the pastoral office ${ }^{8}$ of the church is both to care for its members, but also to make the 'government aware of its failures and mistakes that necessarily threaten its governmental office' (Bonhoeffer in Green \& DeJonge 2013:714).

As will be shown, both the church and the state fail God and the common good of the citizens when the relationship between the church and the government are polluted and compromised. The church and the state each have a responsibility to safeguard the role and function of the other. When one oversteps its bounds both are in error (one for committing the error, and the other for allowing it to take place) (cf. Bonhoeffer in Green \& DeJonge 2013:711).

The complexity of the relationship between the post-apartheid church and the state stems from the positive role that the churches, and particularly the MCSA, played in the deconstruction of apartheid and the ushering in of democratic rule. South Africa's first democratically elected president, Nelson Mandela, noted with great affection the important role that his denomination played in the struggle to end apartheid. ${ }^{9}$

8 Bonhoeffer understood that the 'pastoral office is the power set in place by God to exercise spiritual rule with divine authority. It emerges not from the congregation but from God' (Bonhoeffer in Green \& DeJonge 2013:700).

9 Of course there were many churches and faith based groupings that played as significant, and an even more significant, role in working to end apartheid than the role played by 
Methodist leaders were prominent among the prophets who refused to bow to the false god of apartheid. Your ministers also visited us in prison and cared for our families. Some of you were banned [including Peter Storey]. Your Presiding Bishop [Dr Stanley Mogoba] himself shared imprisonment with us for some years on Robben Island. (Mandela 1994).

It is not surprising that with such strong solidarity in the fight against apartheid, such deep care for political activists and their families, and even the personal faith convictions of many significant struggle leaders, that there would be a close relationship with the largest Christian denomination in South Africa after 1994.

The concern at present is that both the church and the state seem to seek to misuse the relationship that exists between the state, political parties and the church in order to engage one another for undesirable ends. From the side of the church it could be to build relationships with undeserved power and wealth. From the side of the state and political parties it could be to co-opt the church as an electoral constituency, and in so doing negate its witness and work in the world.

In the lead up to the 2014 national elections there was increasing rhetoric of a religious character in the speeches and pronouncements of ANC politicians. The most public display around this were the activities of the Rev Vukile Mehana, the Chaplain General to the African National Congress at the time, who defended President Jacob Zuma's statement that persons who voted for the ANC would go to heaven, while those who voted for other parties would go to hell (Mehana, 2011). Just before the 2014 elections Rev Mehana, who is a very senior minister in the MCSA (serving on the denomination's executive, holding the portfolio of human resources management) came in the spotlight for encouraging pastors in Cape Town to solicit votes for the ANC where he said, 'You cannot have church leaders

the Methodist Church of Southern Africa (cf. the following Elphick \& Davenport 1997; De Gruchy 2005; Elphick 2012; Plaatjies-Van Huffel \& Vosloo 2013). However, for the purposes of this article I shall primarily focus on the role of the Methodist Church of Southern Africa, and in this instance upon one of its most famous members, Nelson Mandela. Please see a detailed discussion on the relationship between Nelson Mandela and the Methodist Church in Mandela and the Methodists (Forster 2014). 
that speak as if they are in opposition to government... God will liberate the people through this (ANC) government' (Phakathi 2014).

Rev Mehana would have done well to heed Storey's warning that, 'the years since 1994 have surely persuaded us that democracy is not to be equated with the arrival of the reign of God' (Storey 2012:5).

As inequality has increased, suffering and poverty have remained, and in some parts increased due to a lack of transfer of privilege, wealth and power from white South Africans, coupled with government corruption and a lack of service delivery, political intolerance has increased, it has become a blight upon the church that it so openly supported a particular political party.

This context could be equated with what the Kairos document described as 'state theology' (cf. De Gruchy in Forrester, Storrar \& Morton 2004:50-51; Huber \& Fourie 2012:111; Boesak 2015:15)

A sentiment of dissatisfaction with the government has emerged within the South African churches. ${ }^{10}$ The Methodist Church of Southern African, in particular, has expressed dissatisfaction at the relationship between the governing party and senior Church members and ministers. At its September 2014 National Synod (called the Conference of the Methodist Church of Southern Africa) pressure from clergy and laity in the denomination forced the denominational leaders to take a stand to withdraw chaplains from political parties. The Presiding Bishop of the Methodist Church of Southern Africa, the Rev Siwa, noted that Methodist ministers may not 'take an official position [hold office], but they can minister to people both inside and outside political parties'. He went on to say that holding an office 'becomes worse if there are political factions or a conflict between political parties. A minister should be above that' (Mataboge 2015). It must be noted that Rev Siwa has proven to be a bold and impartial Church leader who has frequently taken courageous decisions to ensure that the MCSA retains

10 In the wake of the South African Constitutional Court judgement against the security upgrades to President Jacob Zuma's private residence (cf. Full judgement: Constitutional Court rules on Nkandla [Online], 2016) the South African council of Churches issued a statement urging the President and the governing African National Congress 'to assist the president to resign, in the best interests of the country' (SACC 2016). 
relative independence from the state and public integrity. ${ }^{11}$ However, the formal withdrawal of chaplains from political parties was long overdue, and this together with the conflict over the election of the Presiding Bishop, displayed some distance in thinking between the formal leadership, the members of the denomination, and senior clergy and laity. Many had begun to wonder whether the MCSA might not have capitulated to a new form of 'state theology', or perhaps a disengaged 'church theology' because of its slowness to act and speak out on the complicit political relationship between the denomination and the governing party.

While these actions are a step in the right direction from the leadership of the denomination, it would seem that there is still a long way to go for the church to exercise its pastoral and prophetic responsibility to the nation and the state. The last parliamentary census showed that $65 \%$ of current parliamentarians said that they are members of the Methodist Church of Southern Africa.

\section{Methodist polity on church and state}

Having sketched something of the complexity of the current situation it is important to dig a little deeper and ask the question 'what is the nature of a Methodist theology and polity of church and state?'

The most explicit, yet ambiguous, formal statement that the MCSA has made on the relationship between the church and the state, as expressed through its ministers, is to be found under the heading 32. Membership of political parties by ministers in the Methodist Book of Order:

11 In a statement from the Bishops of the Methodist Church of Southern Africa (under the signature of the General Secretary), it was revealed that there are tensions between parts of the governing party (the African National Congress) and the Presiding Bishop. The statement called on Methodist clergy and laity to 'refrain from bringing the church into disrepute' and called on all members to cease to make 'accusations against the current presiding Bishop' and to ignore social media posts that call for Methodists to vote for particular candidates, and not for the Rev Siwa in the upcoming elections for the Presiding Bishop since Rev Siwa had been 'vocal in calling for the President to step down' (Morgan 2016). The letter urged members 'not to bring the church into the fray of South Africa's political tensions'. Rev Siwa stated, in response to the Constitutional Court Judgement on Nkandla, '[t]hese events call for President Zuma to do the honourable thing and resign to save himself, the ANC and the nation as a whole from further embarrassment and ruin' (Siwa 2016). 
The Church has an obligation to act as mediator on behalf of God in society and therefore Ministers should seriously examine their conscience whether to be seen to be members of any political party. (Methodist Book of Order: The Laws and Discipline of the Methodist Church of Southern Africa 2014:226, Section 32).

Thus, it would seem that the denomination regards it as a matter of individual conscience whether a member of the church, or its clergy, should hold membership in a political party. Some have contended that this is a weak statement and that it may be an indication either that the church has subtly given over to the power of political parties and is adopting a form of 'state theology', or that it is engaged in what the Kairos document of 1985 called 'church theology' (Kairos Theologians 1985:15-17; De Gruchy in Forrester et al, 2004:51; Huber \& Fourie 2012:110-114; Boesak 2015:15)

However, I don't believe that the either point can be made convincingly. First, individual members, even ministers, of the Church can surely not be expected to remain outside of political engagement since this a common to all citizens? Second, the denomination is clearer on the matter of holding office in a political party.

A Minister who takes up a party-political post or any other appointment that Conference or the Connexional Executive considers as compromising the independence of the Church in its witness, shall resign from the Ministry, failing which they shall be deemed to have resigned. (Methodist Book of Order: The Laws and Discipline of the Methodist Church of Southern Africa 2014:43, Section 4.91). ${ }^{12}$

12 There are two other pertinent sections of church law that relate to this matter:

Secondment shall only be granted if the position is considered to be in harmony with the ministry and mission of the Methodist Church of Southern Africa. It shall not be granted for positions of a party-political nature, or any appointment which compromises the necessary independence of the Church in its witness to the Gospel in society. (Methodist Book of Order: The Laws and Discipline of the Methodist Church of Southern Africa 2014:44, Section 4.93.1)

Then in relation to church property there is the following stipulation:

...no party political electioneering shall be held on Trust property. However, it may be used in the promotion of good governance such as polling stations, voter registration, political monitoring training, refugee shelter and similar activities that would foster 
However, the most explicit discussion on the current stance of the MCSA on the relationship between the church and the state is to be found in section 31 of the Book of Order entitled Politics and Religion (Methodist Book of Order: The Laws and Discipline of the Methodist Church of Southern Africa, 2014:224-226). This section begins with the following affirmation, 'It is our belief that the lordship of Christ extends to all of life, including the political, social and economic areas of our existence' (Methodist Book of Order: The Laws and Discipline of the Methodist Church of Southern Africa 2014:224). This would certainly seem to resonate with Bonhoeffer's perspective, as will be discussed in a later section.

The paragraph following the one cited above offers a balanced view of the relationship between the church and the state arguing the importance of its understanding of the principle of Romans 13 i.e., that all true authority ultimately derives from the authority of God. Moreover, that there may be instances in which a Christian is called upon to 'obey God rather than humans', citing Acts 5:29 (Methodist Book of Order: The Laws and Discipline of the Methodist Church of Southern Africa 2014:224). ${ }^{13}$

So, it would seem that the denomination's polity is ambiguous in some instances, and clearer in others. What of Methodist Theology?

\section{Wesley and Wesleyanism on church and state}

Let's move beyond current MCSA current polity to see if there is any insight to be gained from the sources of broader Methodist theology and polity. We shall do so by considering the work and witness of one of the founders of Methodism, John Wesley.

John Wesley lived in the latter part of the eighteenth century in England, and died an Anglican Priest (the established church in England). Like Bonhoeffer, who started out as a minister of Lutheran Church in Germany (which in some locations was a Landeskirchen, having formal contracts

neighbourliness, justice and mercy. (Methodist Book of Order: The Laws and Discipline of the Methodist Church of Southern Africa, 2014:129, Section 10.36.8)

13 This accords, in tone at least, to what Bonhoeffer stated in his article The Jewish-Christian Question as a Status Confessionis, 'Pastors are not state officials. Hence, official [state] regulations cannot be applied to them under any circumstances' (Bonhoeffer in Green \& DeJonge 2013:379). 
with the state), we know that Wesley was also willing to take on both the state (on the matter of slavery for example ${ }^{14}$ ) and the church (on the matter of 'sacramental starvation' in the colony of North America) in his context.

Wesley's engagement with the state takes place in an interesting time in history, and his context certainly cannot be equated without remainder to the form of constitutional democracy that contemporary Methodists have in South Africa, or even the context of rising National Socialism that characterized Bonhoeffer's context. However, Wesley did have some democratic rights since he was among a small minority of persons who had the right to vote. The basic conditions to be able to vote in Britain at that time where that one was male, over the age of 21 and an owner of propertyWesley did not fall into this category. However, there was one further inclusion, and that was that graduates of Oxford University and Cambridge University had a right to vote (which meant that John, who was a student at Christ Church, and later a fellow of Lincoln College, Oxford University) had voting rights (Field 2015:2). As such we can conclude that Wesley was educated and had a measure of agency to engage the government, and laws of government, and that his influence and agency increased as the public profile of Methodism increased within eighteenth century England. Bosch writes,

Wesley was a 'Tory' in his political persuasions. Politics for him was so important that he did not hesitate... to write to the King; nor did he hesitate to challenge the American situation, as the war of her independence began to loom; nor did he fail to address, what he considered to be the political needs of the people in England, and in Ireland particularly. (Bosch 1995:150)

In 1774 Wesley published a pamphlet for public consumption and dissemination among the growing band of Methodist preachers and members of Methodist societies, it was entitled Thoughts upon slavery. The intention of the pamphlet was to address not only the issue of slavery, but to cause slave owners to reconsider their views on slave ownership. When considered in the light of what was said above about political agency among members of English society at the time, it is interesting to note that Wesley

14 See John Wesley as Public Theologian for an example of such engagement (Field 2015). 
clearly understood that he had to address issues of public and political concern from different points of view. In some instances he would have to use the constituency of Methodist popular prominence, or his social capital as a socially prominent Anglican Priest (Oxford educated) to engage the formal structures of government - the public of society. ${ }^{15}$ While it is not the same, it could be likened in a cautious way to the process of 'policy engagement' in contemporary discourse. At other times he would seek to address the public of the church, through a pamphlet or sermon of which many are published on a wide range of social and theological issues. And in other ways, and at other times, he would address himself to individual Christians on topics of political, social or civil concern. Field explains the extent to which Wesley went to engage the church (as institution, with its officers and officials, as well as individual members) and the government of his time on this issue of justice. Wesley,

...became a supporter of the Society for Abolition of the Slave Trade when it was founded in 1787. He used the Arminian Magazine which he published as means of instructing and encouraging his followers; to persuade Methodists to oppose slavery, to support the Society for Abolition of the Slave Trade, and to petition parliament to end slavery. In a short and cryptic letter to one of his travelling preachers, Henry Moore, he referred to a note that Moore had sent to the other preachers with the statement: 'I would do anything that is in my power toward the extirpation of that trade which is a scandal not only to Christianity but humanity. ${ }^{16}$ Presumably the note encouraged the preachers to oppose slavery. Symbolically the last letter he wrote before his death was to William Wilberforce supporting him in his struggle to have the slave trade abolished.

Field further notes that central to Wesley's argument on the emancipation of slaves in his 1774 booklet Thoughts upon slavery was a 'secular' legal polemic of slavery in law (not only a theological argument on personhood and contextually appropriate concepts of human dignity). He stated:

15 Please refer to (Tracy 1975, 2014) for a detailed and helpful discussion of the public of society at large, the public of the church and the public of the academy.

16 John Wesley, The Letters of John Wesley, ed. by John Telford, volume 8, (Wesley 1931:207). 
'Liberty is the right of every human creature, as soon as he breathes the vital air, and no human law can deprive him of that right he derives from the law of nature. ${ }^{.17}$

In addition to the above, Wesley was also willing to disobey both the laws of the state and church polity when he felt that either, or both, were in error. Wesley framed such acts of civil and ecclesial disobedience within his understanding of the exercise of 'Christian conscience' (Bosch 1995:158). Simply stated, there may be times where the Christian community, or individual Christians, may be called upon to follow their conscience and in so doing break the law of government and church polity (Bosch 1995:158160). Bosch writes that, 'Christian conscience, of which Wesley held very strong views, must be alert and active in the spheres of 'Religious', 'Civil', 'Political' and personal freedoms, if it is to enable man [sic] to do and to be all that God intends for him' (Bosch 1995:158-159).

Perhaps the clearest example of such disobedience was the ordination by John Wesley of Richard Whatcoat and Thomas Vasey to serve as priests on 2 September 1784, and Thomas Coke as a Superintendent Minister (who subsequently ordained Francis Asbury as a priest) (cf. Puglisi 1997:155; Missouri 2009:137; Andrews 2010:66; Vickers 2013:72; Richey 2015:22). The problem with these ordinations was that John Wesley was not a Bishop and so did not have the ecclesial authority to ordain persons to ministry by doing so he was falling foul of both the law of the state and the state church. However, his concerns that American Christians were being 'starved of the sacraments because of the lack of clergy' (Grass 2008:95) and the withdrawal of ordained clergy to preside over the sacraments in America by the Monarch and the Church of England because of the Declaration of Independence from Britain (Vickers 2013:72) caused him to take matters into his own hands. He decided to ordain and send clergy to America to serve the Christians there. This act of disobedience against the Church further deepened the split within the Church of England that would eventually lead to the establishment of the Methodist Church as a separate denomination after Wesley's death. ${ }^{18}$

17 Wesley, Thoughts upon Slavery 5.6. In The works of John Wesley (Wesley 1872:vol. 11:79).

18 Another example of Wesley's courage to stand against ecclesiastical law was the employment of un-ordained laity preach and his own preaching in the open air - which 
Many other examples of social, political, civil and ecclesial engagement could be cited to support the view that Wesley was comfortable with both civil and ecclesial disobedience on matters of Christian conscience. For the purposes of the argument of this paper it is clear that Wesley respected the role of the state (Monarch) in his time, and also the polity and authority of the Church. However, where he felt that either, or both, were not acting in accordance with divine will, or against the interests of the common good as he understood it, he showed that he was willing to act in accordance with his conscience and take a position in conflict with that of the state or the church.

\section{Southern African Methodism - church and state}

Henry Rack argues that Wesley's balance between personal piety and social holiness took shape as a response to the context in which Wesley lived. The needs of the poor and disenfranchised in $18^{\text {th }}$ century England led him to formulate clear and pragmatic strategies for social development, upliftment, and reform, whilst his experience within the Church of England led him to emphasize the need for personal piety (Rack 1992:672).

So, from the above we have seen that God has placed a particular missional emphasis with the Methodists. However, this emphasis took on a particular shape when it was planted in Southern African soil. ${ }^{19}$ Southern African Methodism inherited its social conscience from its British Methodist roots in England. The Methodist Church of Southern Africa was an important contributor towards the church's struggle against apartheid - in fact the Methodist Church was the only denomination as a whole to be banned under Apartheid law (12 January 1978), (Kalley, Schoeman \& Andor 1999:435).

was considered a contravention of the Conventicle Act of 1644. It was also considered a contravention of church polity to establish Methodist societies and allocate buildings for their use for worship (cf. Gunter 1989:45, 91). For a general discussion of Wesley's engagement with ecclesial and political authorities of his time please see (Weber 2001).

19 Please see Methodism in Southern Africa for a summary of how Methodism came to South Africa and for further detail on how the Southern African Methodists came to adopt and adapt the notions of personal holiness and social holiness in their mission and ministry (Forster 2008a:79-87). 
The Methodist Church sought to address the evil of apartheid both as a church engaging the government and state, for example accusing the government of terrorism against it citizens (Gish 1985:109), but also as a church engaging its own structures, members and doctrines in transformation and justice (Forster 2008a:107-115). As a denomination, and a member of the South African Council of Churches, the MCSA lobbied government, made petitions to the courts and sought to change the political processes of the land. As a church it allowed the development of a caucus within the denomination (the Black Methodist Consultation) ${ }^{20}$ to establish black leadership in the denomination, it took policy decisions (1958, 'One and undivided') to disobey pass laws and the group areas act, the 'Obedience' 1981 campaign to remain resolute to the establishment of a just, non-racial nation, and the 'Journey to the New Land' of the late 1980's and early 1990's that would model a 'New South Africa' for the nation even if the state would not support or allow it. The MCSA was operating as a prophetic church at all three levels, denomination, congregation and individual members.

However, after the transition to participatory democracy in 1994, and the collapse of ecumenical structures (such as the SACC), the church struggled to maintain this consistent, independent, prophetic witness (cf. Bentley 2013; Forster 2014). As stated earlier in the paper, perhaps it is because so many Methodists were members of the liberation movements, or that so many of the post-democratic leadership took senior positions in the governing party and the state, the MCSA began to fall silent, and at times defend and shelter the actions of the new government.

\section{Bonhoeffer's Theological Position Paper on State and Church}

Dietrich Bonhoeffer's view of the role of the church and the state is a complex one. As with the rest of Bonhoeffer's theological contribution it is deeply Christocentric in origin and character. For Bonhoeffer Christology and ecclesiology are inextricably bound to one another (De Lange 2007:13). However, as De Lange rightly points out, his political theology (and so

20 Please see the superb article on the Black Methodist Consultation by Mtshiselwa for more detail on this important aspect of the church's history (Mtshiselwa 2015:1-9). Also please see, (Forster 2008b). 
his views on the relationship between the church and the state) shifted significantly throughout his lifetime. It would seem that there are at least three distinguishable phases to his thought: The first period (around the time of the publication of Sanctorum Communio and Act and Being), is characterized by its engagement with the experiment of democracy in the Weimar republic with an emphasis on social cohesion and an emphasis on social justice (De Lange 2007:10). Christ is to be found among the poor and the ordinary working persons of society who lack power and a sense of politically centered identity. The second period (around the time of the publication of The Cost of Discipleship, after Hitler's rise to power), is characterized by working out what it means to be a persecuted Church in the midst of a dictatorship that actively violates the humanity of some citizens (De Lange 2007:10-11). In this period the Christ is recognized in the Jew. While the Bonhoeffer's social location was the academy in the preceding period, he is now located within the Confessing Church. His thoughts are shaped in academic texts in the previous period whereas the contribution in this period has the tone and tenor of the Church, namely sermons, pastoral publications and meditations. The third period of Bonhoeffer's political thought (which is found in the posthumous publication of Ethics and Letters and Papers from Prison) is characterized by a strong resistance among citizens against the totalitarianism of the Nazi system, offering moral and religious foundations for the construction of a new society after the end of the war. Here, the Christ is to be identified in the 'good citizen who takes responsibility' in the current reality, living courageously for a better future (De Lange 2007:11). Here Bonhoeffer's social location is his family home (in the early 1940's when he started working on Ethics) and later the limited space of his prison cell (the location for the writing of Letters and Papers from Prison).

The focus text for this paper is Theological Position Paper on State and Church which was written around the time of Ethics. As suggested above, his political thought developed in the subsequent years. Some aspects of this development will be important in the present discussion, however, for a thorough treatment of this topic please see Pacifism, just war, and tyrannicide: Bonhoeffer's church-world theology and his changing forms of political thinking and involvement (Gides 2011). 
One of the consistent aspects of Bonhoeffer's theological thinking throughout his work is the mandates given to the church and the state by God. When the state operates as it should, and the church operates as it should, God's will for society is enacted and there should be harmony between the church and the state, '...it becomes apparent that what is best for government will also be best for the relationship of government and church' (Green \& DeJonge 2013:715).

However, when there is error in either the church or the state, each has some claims upon the other. As for the church, Bonhoeffer writes:

Part of the church's role as guardian is to call sin by name and to warn human beings of sin... warning against sin extends quite publically to the church-community, and those who will not hear it bring judgment upon themselves. It is the responsibility of the pastoral office to take seriously the proclamation of the kingly reign of Christ and through direct, respectful speech to make government aware of its failures and mistakes that necessarily threaten its governmental office. (Green \& DeJonge 2013:713)

From the side of the state, Bonhoeffer contends that while the office of government remains independent of 'religious decision', it nevertheless has 'the responsibility of governmental office to safeguard, indeed to praise, the devout - i.e., to support the cultivation of religion... The governmental office as such thereby remains religiously neutral and only inquires after its own task.' (Green \& DeJonge 2013:712).

Bonhoeffer makes a further comment that is germane to the discussion at hand - where the state oversteps its bounds and furthers the aims of a particular denomination, or aligns itself with a particular religious tradition, it is in error: 'If persons in government are Christian, then they must know that Christian proclamation occurs not by the sword but by the word' (Green \& DeJonge 2013:712).

In summary, Bonhoeffer saw that the state had the responsibility of governing the nation for the sake of the common good of all of its citizens (those who adhere to other faiths, or no faith, as well as those who happen to be Christian). The church has the responsibility of fulfilling its pastoral calling of proclaiming the Gospel in truth - naturally this would have 
political consequences, but its primary intention is not politics, but rather the aims of Christ in the polis.

Both the state and the church should be critiqued when they fail in their respective roles and responsibilities. There are some churches, and some in the churches, who are in danger of being considered state theologians. ${ }^{21}$ Some have done so in error, others seem to have bought into a heretical theology and aligned themselves with power and wealth, seeking to achieve the aims of the state as a political entity, in many instances these are counter to the aims of Christ.

When the state uses its power to co-opt the church (and its officers) for political aims, it is also in error in not fulfilling its mandate towards its citizens. Namely, it is failing to maintain a just, fair and religiously open environment for the common good. Where the state co-opts and domesticates the church to use it for its own political aims it faces God's judgment.

A consequence of losing a true theological perspective on the intentions of God's aims for both the state (governance) and the church is that both lose their true mandate and perspective within God's will. He writes,

Government and church are bound, and bound together, by the same Lord. Government and church are distinguished from each other in their task. Government and church have the same sphere of action, human beings... what matters is giving concrete room in every given form for the relationship actually established by God and entrusting the way it develops to the Lord over government and the church. (Bonhoeffer. In Green \& DeJonge 2013:714-715).

21 An argument could be made that the term 'state theology' is too narrow to adequately address the complexity of the current power dynamics in South African society. Not all abusive and coercive power that operates in South African society can be directly related to the power of the state (and a theology that supports it). Political parties exercise corrupt and abusive power, as do economic, cultural and social entities. Perhaps the term 'imperial theology' might be more apt to use in future arguments of this nature, since it shows that wherever the principles of empire operate (apart from the state), and they are supported by theology, a form or imperial theology can be identified and engaged? 
Having considered Bonhoeffer's perspectives from his Theological Position Paper on State and Church, we shall move on to considering some cautions and suggestions for the MCSA at present based on the above.

\section{Cautions and suggestions}

Bonhoeffer concludes his Theological Position Paper, with three comments on the most appropriate form of the relationship between the church and the state. These serve as good guidelines, cautions and suggestions of the MCSA in its relationship with its members in government and the governing party, and in its formal relationship with the state, as well as its pastoral witness in South African society. Each of these can be related in some ways to three broad expressions of the concept of Church (i.e., Church as denomination, church as local congregation or community, and church as individual members who are salt and light in society. ${ }^{22}$ )

The relatively best form of the state will be that in which it is most clear to the state that all true government derives its authenticity and authority from God (Green \& DeJonge 2013:715). South African Methodist Bishop and Theologian, Peter Storey, writes, 'Rulers are accountable. They have a special responsibility to 'shepherd' their people because 'their' people are not actually theirs, but God's (Ezek 34). Therefore, rulers are accountable to God. 'He did what was right in the sight of the Lord,' is the supreme biblical accolade for rulers, but that phrase is sadly outnumbered in the Bible by its opposite: 'He did what was evil in the sight of the Lord' - I and II Kings.' (Storey 2012:3). The church has an important role to care for, and remind, the secular rulers that they are accountable for their choices and actions, and that their authority is intended to be used for the common good of all of the nation's citizens.

1. The relatively best form of the state is where its power is not compromised (either by the state compromising on its role for governance, or by the church bringing it into error and weakness), and so it can be both sustained and secured for the common good.

22 For a detailed discussion of these concepts please refer to (Smit 1996; Philander 2011; Forster 2015; Forster \& Oosterbrink 2015). 
Elsewhere this concept was argued as follows, 'Christians have a Godgiven responsibility to engage any power, whether an individual or an institution, that acts contrary to the principles of the Kingdom of God and the Gospel of Christ. Every believer is to be a prophet, listening for the will of God in society and living to see that will enacted. This is best done where the State affords religious freedom to its citizens - creating sufficient space for them to express their convictions.' (Bentley \& Forster 2012:82). Prozeky argues that such a state, which is religiously neutral while protecting the religious freedom of its citizens, is the best form of state since it not only protects the rights of all its citizens, but also allows sufficient religious freedom for persons of faith to participate in working for the common good (Prozeky 2009:249-250).

2. The relatively best form of state is where the state expresses its solidarity with its subjects through just action and true speech. Storey opens his argument on the relationship between the church and the state by quoting from Scripture:

Someday there will be a king who rules with integrity and national leaders who govern with justice. Each of them will be like a shelter from the wind and a place to hide from storms. They will be like streams flowing in the desert, like the shadow of a great rock in a barren land. Their ears shall be open to the needs of the people. - Is 32: 1-3.

'Some day...' is the call to both the church and the state to live in the present for an eschatological hope given by God for the common good of all people and creation. This is the responsibility of both of these spheres of society. Bonhoeffer reminds us that Christians in all spheres of society are accountable and responsible to engage politically to change policy to maintain justice and the role of the government, and by the same token to keep the church pure and faithful in the exercise of its pastoral and prophetic office. If a government doesn't respond to such a proclamation and engagement with the state then the church has a responsibility to protect the least and the most vulnerable over and against the injustice and inadequacy of government (Green \& DeJonge 2013:713-714). Finally individual Christians have a role to play in this scheme of things, Bonhoeffer 
reminds us that each individual Christian has a responsibility to 'safeguard the purity of their offices and tasks in the polis' (Green \& DeJonge 2013:714).

So, is the MCSA in danger of being a state church? No, but it is in danger of inadvertently embodying and propagating a form of state theology that could harm the identity and role of both the state and the church. There is a place for all of the churches in South Africa to remind the governing party, and the MCSA, that such a theology, and the relationship that stems from it, is not in the interest of either the church or the state, and that it is an offence to the nation, to the intention of God, and that it jeopardises the common good of South Africans.

\section{Bibliography}

Andrews, DE 2010. The Methodists and Revolutionary America, 17601800: The Shaping of an Evangelical Culture. Princeton University Press.

Bentley, W 2013. Defining Christianity's 'prophetic witness' in the postapartheid South African democracy. Studia Historiae Ecclesiasticae, 39(1).

Bentley, W \& Forster, DA 2012. Between Capital and Cathedral: Essays on Church-State relationships. Pretoria: UNISA Research Institute for Theology and Religion.

Boesak, AA 2015. Kairos, Crisis, and Global Apartheid: The Challenge to Prophetic Resistance. Palgrave Macmillan.

Bosch, LC 1995. The ethical implications of the concept of faith as freedom from society in the theology of John Wesley. University of South Africa.

Conradie, EM \& Pillay, M 2015. Ecclesial Reform and Deform Movements in the South African Context. AFRICAN SUN MeDIA.

De Gruchy, JW 2007. Public Theology as Christian Witness: Exploring the Genre. International Journal of Public Theology, 1(1):26-41.

- 2005. The Church Struggle in South Africa. Twenty-fifth anniversary ed., $1^{\text {st }}$ Fortress Press ed. Minneapolis: Fortress Press. 
De Gruchy, JW \& Villa-Vicencio, C 1983. Apartheid is a heresy. Grand Rapids, Mich.: William B. Eerdmans Publishing Co.

De Lange, F 2007. Against Escapism: Dietrich Bonhoeffer's Contribution to Public Theology. Christian in Public: Aims, Methodologies and Issues in Public Theology, Beyers Naudé Centre Series on Public Theology, 3:141-52.

Elphick, R 2012. The Equality of Believers: Protestant Missionaries and the Racial Politics of South Africa. University of Virginia Press.

Elphick, R \& Davenport, TRH 1997. Christianity in South Africa: A Political, Social, and Cultural History. University of California Press.

Field, D 2015. John Wesley as a Public Theologian - The Case of Thoughts upon Slavery. Scriptura: International Journal of Bible, Religion and Theology in Southern Africa.

Forrester, DB, Storrar, W \& Morton, A 2004. Public Theology for the $21^{\text {st }}$ Century: Essays in Honour of Duncan B. Forrester. A\&C Black.

Forster, DA 2008a. God's mission in our context: Critical questions, healing and transforming responses. In Bentley, W \& Forster, DA (eds.). Methodism in Southern Africa: A celebration of Wesleyan mission. Kempton Park: AcadSA Publishers. 70-99.

- 2014. Mandela and the Methodists: Faith, fallacy and fact. Studia Historiae Ecclesiasticae, 40(Church History Society of Southern Africa $40^{\text {th }}$ Anniversary supplement):87-115.

- 2008b. Prophetic witness and social action as holiness in the Methodist Church of Southern Africa's mission. Studia Historiae Ecclesiasticae, XXXIV, (1):411-434.

- 2015. What hope is there for South Africa? A public theological reflection on the role of the church as a bearer of hope for the future. HTS Teologiese Studies / Theological Studies, 71(1):1-10.

Forster, DA \& Oosterbrink, JW 2015. Where is the church on Monday? Awakening the church to the theology and practice of ministry and mission in the marketplace. In die Skriflig/In Luce Verbi, 49(3). 
Full judgement: Constitutional Court rules on Nkandla [Online]. 2016.

News24. Available: http://www.news24.com/SouthAfrica/News/full-textconstitutional-court-rules-on-nkandla-public-protector-20160331 [Accessed 2016, May 31].

Gides, DM 2011. Pacifism, just war, and tyrannicide : Bonhoeffer's churchworld theology and his changing forms of political thinking and involvement. Eugene, Or. : Eugene, Or. :

Gish, SD 1985. The Methodist Church and apartheid in South Africa: a paper. Northwestern University.

Grass, T 2008. Modern church history. SCM Press.

Green, CJ \& DeJonge, M eds. 2013. The Bonhoeffer Reader. Philadelphia: Fortress Press.

Gunter, WS 1989. The Limits of 'Love Divine': John Wesley's Response to Antinomianism and Enthusiasm. Kingswood Books.

Hansen, LD 2007. Christian in public aims, methodologies, and issues in public theology. $1^{\text {st }}$ ed. Stellenbosch: SUN Press.

Huber, W \& Fourie, W 2012. Christian Responsibility and Communicative Freedom: A Challenge for the Future of Pluralistic Societies: Collected Essays. LIT Verlag Münster.

Kairos Theologians. 1985. Challenge to the Church: A Theological Comment on the Political Crisis in South Africa. [Online]. Johannesburg: Kairos Theologians. Available: http://www.sahistory.org. za/archive/challenge-church-theological-comment-political-crisis-south-africa-kairosdocument-1985

Kalley, JA, Schoeman, E \& Andor, LE 1999. Southern African Political History: A Chronology of Key Political Events from Independence to Mid-1997. Greenwood Publishing Group.

Kim, SCH 2011. Theology in the Public Sphere. Hymns Ancient and Modern Ltd. 
Koopman, Nico 2011. Modes of prophecy in a democracy, in Heinrich Bedford-Strohm \& Etienne de Villiers (eds.). Prophetic witness: an Appropriate Mode of Public Discourse in Democratic Societies? Theology in the Public Square / Theologie in der Offentlichkeit, LIT Verlag. 181-192.

Lategan, BC 2015. Hermeneutics and Social Transformation - A selection from the essays of Bernard C. Lategan. Smit, DJ (ed.). Stellenbosch: SUN Press.

Maluleke, TS 2011. Reflections and Resources The Elusive Public of Public Theology: A Response to William Storrar. International Journal of Public Theology, 5(1):79-89.

Mandela, N 1994. Address by President Nelson Mandela to the Annual Conference of the Methodist Church [Online]. Speech. Available: http:// www.anc.org.za/show.php?id=3685 [Accessed 2011, January 4].

Mataboge, M 2015. ANC hopes Methodists will minister to them. Mail \& Guardian. [Online]. Available: http://mg.co.za/article/2015-05-26-the-methodistchurch-may-no-longer-forsake-the-anc/ [Accessed 2015, September 17].

Mehana, V 2011. Zuma's remarks explained - ANC Chaplain General [Online]. Available: http://www.politicsweb.co.za/politicsweb/view/politicsweb/en/ page71639?oid $=220386 \&$ sn $=$ Detail $\&$ pid $=71639$.

Methodist Book of Order: The Laws and Discipline of the Methodist Church of Southern Africa. 2014. Cape Town: Methodist Publishing House.

Missouri, JWAP of HU of. 2009. American Saint : Francis Asbury and the Methodists: Francis Asbury and the Methodists. Oxford University Press, USA.

Morgan, C 2016. MCSA statement on Social Media and the Election of the Presiding Bishop.

Mtshiselwa, N 2015. The emergence of the Black Methodist Consultation and its possible prophetic voice in post-apartheid South Africa: original research. HTS: Theological Studies, 71(3):1-9. 
Phakathi, B 2014. Pastors will not help ANC win votes, says DA [Online]. Available: http://www.bdlive.co.za/national/politics/2014/02/06/pastors-will-nothelp-anc-win-votes-says-da

Philander, NC 2011. Die rol van die kerk as een van die instellings in die samelewing wat mense moreel vorm. Dutch Reformed Theological Journal / Nederduitse Gereformeerde Teologiese Tydskrif, 52(1 \& 2):174185.

Plaatjies-Van Huffel, M-A \& Vosloo, R 2013. Reformed Churches in South Africa and the Struggle for Justice: Remembering 1960-1990. Stellenbosch, South Africa: AFRICAN SUN MEDIA.

Prozeky, M 2009. Is the secular state the root of our moral problems in South Africa? Alternation, 3.

Puglisi, JF 1997. The Process of Admission to Ordained Ministry: The first Lutheran, Reformed, Anglican and Wesleyan rites. Liturgical Press.

Rack, HD 1992. Reasonable enthusiast: John Wesley and the rise of Methodism. Epworth.

Richey, RE 2015. Methodism in the American Forest. Oxford University Press.

SACC 2016. Statement: Resignation of President Jacob Zuma - South African Council of Churches (SACC). South African Council of Churches (SACC). [Online]. Available: http://sacc.org.za/news/statementresignation-president-jacob-zuma/ [Accessed 2016, May 31].

Siwa, Z 2016. President, Do the honourable thing, say Methodists.

[Online]. Available: http://www.methodist.org.za/news/03312016-1309 [Accessed 2016, April 1].

Smit, DJ 2007. Essays in Public Theology: Collected Essays 1. Stellenbosch, South Africa: AFRICAN SUN MeDIA.

- 1996. Oor die kerk as 'n unieke samelewingsverband. Tydskrif vir Geesteswetenskappe, 2(36):119-129.

- 2013. The Paradigm of Public Theology - Origins and Development Bedford-Strohm, H., Höhne, F. \& Reitmeier, T. (eds.). Contextuality and Intercontextuality in Public Theology, 11-23. 
Storey, P 2012. Banning the flag from our churches: Learning from the Church-State struggle in South Africa, in Forster, D.A. \& Bentley, W. (eds.). Between Capital and Cathedral: Essays on Church and State Relationships. Pretoria: UNISA Research Institute for Theology and Religion. 1-20.

Tandwa, L 2016. SACC is just a government mouthpiece - student leaders. Available: http://www.news24.com/SouthAfrica/News/sacc-is-just-a-govtmouthpiece-student-leaders-20160119.

Tracy, D 1975. Theology as public discourse. The Christian Century, 92(10):287-287.

- 2014. Three Kinds of Publicness in Public Theology. International Journal of Public Theology, 8(3):330-334.

Tshaka RS 2014. A perspective on notions of spirituality, Democracy, Social cohesion and public theology. Verbum et Ecclesia, 35(3).

Vickers, JA 2013. Thomas Coke: Apostle of Methodism. Wipf and Stock Publishers.

Weber, TR 2001. Politics in the Order of Salvation: New Directions in Wesleyan Political Ethics. Kingswood Books.

Wesley, J 1931. 8 The Letters of the Rev. John Wesley. Telford, J. (ed.). London: Epworth Press.

- 1872. The Works of John Wesley. Jackson, T. (ed.). Zondervan. 